Article

\title{
Civil Society Activism under US Free Trade Agreements: The Effects of Actorness on Decent Work
}

\author{
Myriam Oehri
}

Permanent Mission of Liechtenstein to the United Nations, New York, NY 10017, USA; E-Mail: myriam.oehri@nyc.Ilv.li

Submitted: 29 June 2017 | Accepted: 31 July 2017 | Published: 14 December 2017

\begin{abstract}
US free trade agreements comprise unique provisions that enable civil society to present public complaints against labor rights violations occurring in the US or its trade partners. To date, a variety of complainants have used these mechanisms, including (inter)national trade unions, human rights organizations, and a priest. And yet, little is known about the submissions' nature of agency and the effects it has on the procedural continuations to address illicit labor practices. To fill this research lacuna, this article employs a multidisciplinary framework of 'actorness' that measures the submitters' diversity (professionalism/non-professionalism, collectivism/individualism, transnationalism/nationalism) and their effectiveness (rejection/acceptance of submissions and further procedural follow-ups). Combining quantitative examination with in-depth analysis of two diverse cases of actorness, and drawing on expert interviews, public reports, and minutes of meetings, the study reveals that the majority of public submissions were of professional, collective, and transnational nature. However, contrary to what extant literature suggests, this is not a guarantee that they achieve more far-reaching procedural steps in the protection of workers. Non-professional, individual, and national actorness can compensate for the advantages of professionalism, collectivism, and transnationalism.
\end{abstract}

\section{Keywords}

civil society; decent work; free trade agreements; labor standards; public complaints

\section{Issue}

This article is part of the issue "Labour Standards in a Global Environment", edited by Gerda Van Roozendaal (University of Groningen, The Netherlands) and Jan Orbie (Ghent University, Belgium).

(C) 2017 by the author; licensee Cogitatio (Lisbon, Portugal). This article is licensed under a Creative Commons Attribution 4.0 International License (CC BY).

\section{Introduction}

Since the end of World War II in particular, an inclusive international system has emerged. It comprises international institutions such as tribunals that provide direct access and influence to civil society actors and organizations (Hall, Jacoby, Levy, \& Meunier, 2014, p. 14; Keohane, Moravcsik, \& Slaughter, 2000, p. 465).

With the entry into force of the North American Free Trade Agreement (NAFTA) and its side agreement, the North American Agreement on Labor Cooperation (NAALC), in 1994, a new era of labor advocacy has begun. It was the first international trade accord which enabled civil society actors to present complaints with respect to workers' rights violations. Since the NAALC, all US-signed trade agreements have included similar inclu- sive complaint procedures: Chronologically, these are US bilateral trade agreements with Jordan, Chile, Singapore, Australia, Morocco, Bahrain, and Oman; the regional Central American-Dominican Republic Free Trade Agreement (CAFTA-DR) with Costa Rica, the Dominican Republic, El Salvador, Guatemala, Honduras and Nicaragua; and bilateral trade agreements with Peru, Columbia, Panama, and South Korea. They entered into force between 2001 and 2012. The opportunity for civil society actors to present a labor rights complaint in the context of the NAALC and subsequently concluded US FTAs is defined in a Federal Register Note that reads as follows: 'Any person may file a submission with the OTLA [Office of Trade and Labor Affairs, US Department of Labor] regarding another Party's commitments or obligations arising under a labor chapter [of US FTAs] or Part Two of the NAALC'. ${ }^{1}$

\footnotetext{
${ }^{1}$ A submission has to meet certain criteria. See US Federal Register, available at https://www.dol.gov/ilab/media/pdf/2006021837.pdf
} 
When determining the conditions for effective functioning and impact of labor rights promotion through US trade instruments, extant literature has mainly focused on structural and political shortcomings of the enforcement procedure (Nolan García, 2011a, pp. 104-105; Van Roozendaal, 2015, pp. 26-27; Weiss, 2003). The nature of the actors who submit these complaints, however, has hardly gained attention as potential influencing factor. $^{2}$ Such a view becomes all the more relevant since the complaint procedure is 'a flexible, accessible instrument that labor rights advocates can creatively exploit' (Compa, 2002, p. 156). The comparatively low restriction for admittance provides opportunities for civil society actors of various professional, social, and national backgrounds, characteristics that are likely to influence the success of their engagement (see also Freeman \& Hersch, 2005; Keck \& Sikkink, 1999; Risse, 2000).

This study is the first to systematically and comprehensively assess the nature of labor rights complainants in the context of US FTAs. Drawing on an original multidisciplinary theoretical framework of actorness, characterized by professionalism, collectivism, and transnationalism, I provide a differentiated assessment of the complaining parties of the 31 labor submissions presented at the OTLA, US Department of Labor (USDOL). I discuss two diverse cases with regard to their actorness and how they affected the submissions' continuations towards better working conditions: They are the 2011 submission against the Mexican Government under the NAALC and the 2011 submission against the Government of the Dominican Republic under the CAFTA-DR. Data is derived from qualitative, semi-structured expert interviews, and official public reports and minutes of meetings.

The quantitative assessment reveals that labor rights submissions directed at the US in the context of US FTAs are largely dominated by professional (trade unions and/or their confederations), collective (more than one complaining party), and transnational (multi- and/or international origin) complainants. In light of further insights from the qualitative case study, it is argued that these particularities of actorness, unlike extant research suggests, do not automatically lead to the acceptance of a public submission and further procedural steps. Complaints of non-professional, individual, and national nature can be likewise effective if they compensate for the lack of professionalism's, collectivism's, and transnationalism's advantages (e.g., expertise, experience, legitimacy, and international attention).

\section{Actorness in International Labor Politics}

In order to bring structure into the mosaic of various actors presenting labor rights complaints in the framework of US FTAs, a multidisciplinary theoretical framework is developed in this section. It comprises three dichotomous dimensions of actorness (i.e., professionalism/non- professionalism; collectivism/individualism; transnationalism/nationalism) which are influential in international policy making in general and labor rights advocacy in particular. Effectiveness in the context of this study reflects whether US authorities accepted a public submission to be reviewed. In so doing, a case is granted legal validity, which again makes further political and quasi-judicial steps in the enforcement procedure possible. ${ }^{3}$ It is this procedural stage where the submitters' range of influence normally ends. In the qualitative case study, further follow-ups (e.g., public reports of review, recommendations, monitoring) are considered as well.

\subsection{Professionalism/Non-Professionalism}

Today's modern societies are shaped by a variety of professions with unique expertise and interests. In the struggle between labor and capital, trade unions and their confederations have traditionally been considered the major actors transferring the claims of workers. As in many other states, US trade unions have gained important status since the 1930s: 'The labor giants-the AFL-CIO (American Federation of Labor and Congress of Industrial Organizations), the Teamsters, the United Mine Workers, and historic ones like the Industrial Workers of the World or the Knights of Labor-these were venerable institutions, part of our nation's heritage' (Dray, 2010, pp. 5-6). It was in the mid-1950s, when unions in the US reached their highest density, measured by the proportion of workers of the total workforce who were union members. Thereafter, their growth slowed down. Since the mid-1970s, trade unions' density has steadily declined, leading to a weakening of their strength and influence (Freeman \& Hersch, 2005, p. 1). As far as the role of professions in modern life is concerned, it is assumed that limited efficacy makes a jurisdiction, understood as the link between occupation and its work, vulnerable (Abbott, 1988, p. 46). This can also be observed in the domain of labor: With the decline of trade unionism, new labor rights institutions have emerged. They comprise legal service centers, professional organizations, and human rights vigilances, including Amnesty International USA, Oxfam America group, Human Rights Watch, Americans for Democratic Action, and American Rights at Work (Compa, 2008, pp. 230-234, 245; Freeman \& Hersch, 2005, p. 6).

Accordingly, there is little doubt that trade unions do not enjoy full jurisdiction, that is the complete, legally established control over the fight for decent work. However, as the ability of a profession to sustain a jurisdiction lies partly in the power and prestige of its knowledge (Abbott, 1988, pp. 53-54), trade unions seem to have advantages over other labor rights advocates who cannot fully substitute for them (Freeman \& Hersch, 2005, p. 4). As far as expertise is concerned, trade union leaders can increase their skills in the realm of labor activism by

\footnotetext{
2 For exceptions see for instance Nolan García (2011b).

${ }^{3}$ The procedural guidelines include ministerial consultations, arbitral panels, and economic sanctions.
} 
participating in executive training programs. ${ }^{4}$ Moreover, being the voice of labor, trade unions have immediate contact to workers who they represent and thus access to relevant information from the ground (Freeman, 1976, p. 364). In terms of experience, they have had greater chances to navigate through (and potentially undergo learning processes regarding) international complaint systems than other civil society actors. To illustrate, the International Labor Organization (ILO), the UN specialized agency for labor rights matters, allows worker and employer organizations to present complaints regarding labor rights violations. Several US trade unions such as the AFL-CIO and the United Electrical, Radio, and Machine Workers of America have made use of it by (co-)filing complaints in the ILO system (Compa, 2008, pp. 239-240).

Given trade unions' lifetime mandate of labor protection, their expertise and experience, it can be assumed that labor rights submissions of professional actors (i.e., [co-]presented by trade unions or their confederations) in the context of US FTAs are more likely to be accepted for review than those presented by non-professional ones (i.e., other than trade unions). ${ }^{5}$

\subsection{Collectivism/Individualism}

States no longer have the monopoly over domestic and international politics. Instead, in recent decades, a more inclusive international system has emerged, providing access and influence to a variety of civil society actors and organizations (Hall et al., 2014, p. 14). In international law, the right of individuals to present a complaint before an international tribunal is institutionalized in various international court systems (Keohane et al., 2000, p. 465).

In addition to the proliferating opportunities for individual voice in international politics, collective actors such as non-governmental organizations (NGOs), multinational corporations, and foundations have gained increased access to international organization bodies (Tallberg, Sommerer, Squatrito, \& Jönsson, 2014, p. 747). Collective forms of organization which feature voluntary, reciprocal, and horizontal patterns of communication and exchange are also referred to as advocacy networks as 'advocates plead the causes of others or defend a cause or proposition: they are stand-ins for persons of ideas' (Keck \& Sikkink, 1999, p. 91). Such collective entities can include NGOs, research and advocacy organizations; local social movements; foundations; the media; churches, trade unions, consumer organizations, intellectuals; and state actors such as parts of the executive and parliamentary branches of governments (Keck \& Sikkink, 1999, pp. 91-92). Networks not only transfer knowledge and know-how, but they can also contribute to the better coordination of financial resources (Kidder, 2002, p. 290). Moreover, civil society coalitions are more representative than individuals and hence increase legiti- macy (Florini, 2000, p. 233) and cultivate a reputation for credibility with the press (Keck \& Sikkink, 1999, p. 96).

In the world of labor, Freeman (1976) presents several reasons why collective rather than individual activity is necessary to effectively claim workers' rights. First, individuals expressing discontent in the workplace face negative consequences, such as being fired. Retaliation against the entire work force, however, is less likely. Second, as working conditions have a communal nature, their violations create a public goods problem which individuals can hardly solve on their own but rather through collective action. Finally, labor rules require constant monitoring by an entity which has expertise on employment contracts and represents workers. This is traditionally the work of trade unions; individuals can hardly fulfill this task on their own. In a nutshell, 'the marginal costs of exercising rights are likely to be lower for a group of workers than for a single individual. This combination implies that the outcome of individual actions is likely to be inferior to the socially optimal level' (Freeman \& Hersch, 2005, p. 5).

Accordingly, it can be assumed that labor rights submissions presented in the context of US FTAs collectively (i.e., by more than one complaining party) are more likely to be accepted for review than those presented individually (i.e., one complaining party).

\subsection{Nationalism/Transnationalism}

In addition to the increasing integration of domestic civil society actors and organizations in advocacy groups, there is also a tendency of growing cross-border relations. 'Transnational advocacy networks', as Keck and Sikkink (1999) call them, operate across national boundaries on behalf of shared principles, ideas, and values. Such alliances emerge as domestic groups often do not have resources within domestic political or judicial systems. International coalitions may help in expressing their concerns. Moreover, it increases the pressure on states from outside, which is also called the 'boomerang' pattern of influence (Keck \& Sikkink, 1999, p. 93). According to Risse (2000, p. 196), 'transnational pressure turns out to be the single most important cause of change toward initial concessions by the norm-violating government, even more important than pressure from other governments'. In sensitive arenas in particular, transnational advocacy also helps to protect the lives of domestic civil society groups. In contrast to purely national actors and organizations, transnational coalitions have the advantage to exchange funds and services, as well as to generate relevant information quickly and accurately, and to exchange it reciprocally and deploy it effectively (Keck \& Sikkink, 1999, pp. 92-93). Moreover, combining civil society actors from different nationalities, the media coverage is likely to transcend borders and attract global attention (see also Johnson, 2000, p. 62).

\footnotetext{
${ }^{4}$ See for instance the Harvard Trade Union Program established in 1942, available at http://www.law.harvard.edu/programs/lwp/HTUPapply.html

5 This does not mean that organizations engaging in labor affairs other than trade unions do not work professionally.
} 
With the emergence of international labor rules at the latest, transnational advocacy can also be found in the domain of labor. It includes trade unions, NGOs, and other labor rights advocates. As an illustration, telecommunication unions in the US, Mexico, and Canada built an alliance to coordinate actions and mutually assist each other. In the automobile industry, as another example, trade unions in the US, Germany, and Brazil jointly engaged in the formulation of similar, non-discriminatory contracts among the countries. In addition to transnational alliances of national groups, transnational advocacy in the field of labor also occurs through regional groups such as the European Trade Union Confederation and international groups such as Human Rights Watch and the International Confederation of Free Trade Unions (Trubek, Mosher, \& Rothstein, 2000, pp. 11921193, 1196-1197). According to Tilly (1995, p. 21), in a globalizing world with powerful international capital, 'only collective action at an international scale has much prospect of providing gains for labor, or even of stemming labor's losses'. At the more regional level, transnational advocacy is a significant factor for labor rights complaints under the NAALC to be accepted for review (Nolan García, 2011b, pp. 49-50).

Due to pressure from the outside, accurate information collection, exchange of funds and services, as well as international media attention, transnational networks enjoy advantages that national networks do not have. Accordingly, it can be assumed that labor rights submissions presented in the context of US FTAs by a transnational complaining party (i.e., of multi- or international origin) are more likely to be accepted for review than those presented by a purely national complaining party (i.e., of national origin).

\section{Labor Rights Protection in US FTAs: Does Actorness Matter?}

Since the entry into force of the US FTAs, more than 40 labor rights complaints have been submitted to one of the signing parties. A majority of these complaints, namely 31 , were presented before the US OTLA, which is authorized in the US to decide whether a submission is accepted for review. Figure 1 illustrates the number of submissions and the accused governments presented the US OTLA between 1994 and 2016.

Regarding the nature of complainants, 'submissions come from a variety of sources'. ${ }^{6}$ As summarized in Figure 2, more than three quarters of the complaints were (co-)filed by trade unions (or confederations thereof) who traditionally enjoy the jurisdiction of workers' rights promotion. They cover sector-specific unions such as the United Steelworkers and sector-transcending associations such as the AFL-CIO. Those complaints presented without the involvement of trade union actors were designed by new labor advocates, including Human Rights Watch, the International Labor Rights Fund, United Students Against Sweatshops, the National Association of Democratic Lawyers, and legal service centers.

A grand part of the labor cases was not presented by a single complaining entity but as a result of collective advocacy. They range from submissions filed by two groups up to a network of over 90 signatory organizations. Those submissions filed by an individual entitywith the exception of one case whose submitter was a single person-are presented by one organization such as the United Electrical, Radio, and Machine Workers of America. Interestingly, with the exception of one submission presented by the International Brotherhood of

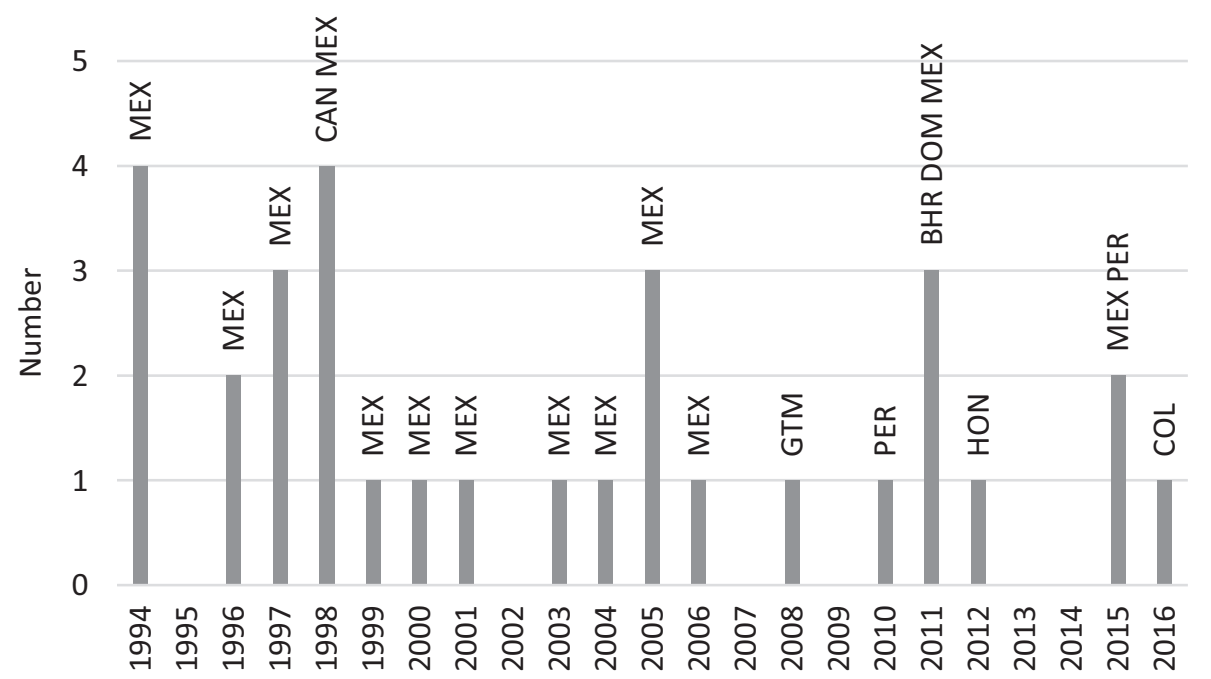

Figure 1. Public submissions to US OTLA.

\footnotetext{
$\overline{6}$ Interview, Director, OTLA, USDOL, June 12, 2013.
} 


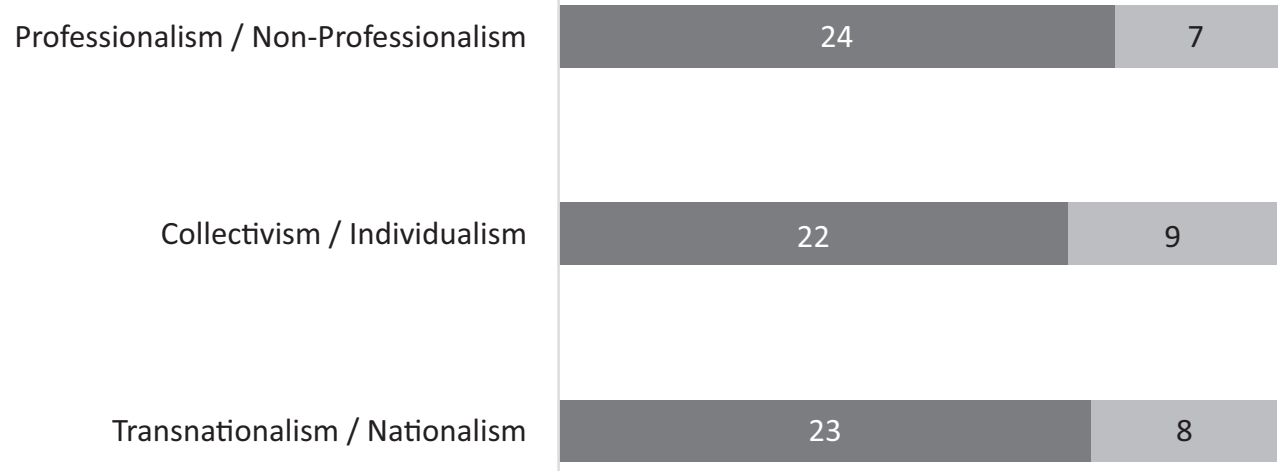

Figure 2. Actorness in public submissions to US OTLA.

Teamsters, all of the individually submitted complaints have a national source.

Overall, slightly more than three quarters of the submissions have a multi-national origin. Either do they combine groups of at least two different nationalities, such as a joint complaint by the Association of Flight Attendants of the US and the Association of Flight Attendants of Mexico, or they involve organizations with an international base, such as the International Trade Union Confederation (ITUC), the International Labor Rights Education and Research Fund, and Human Rights Watch.

In sum, it can be concluded that public labor rights submissions to the US OTLA in the context of US FTAs are largely filed by professional, collective, and transnational complainants. To put it differently, the inclusive complaint mechanism is not merely used by national umbrella trade unions, such as the AFL-CIO: 'often times people think this [complaint mechanism in US FTAs] is really only an AFL-CIO vehicle....I think the longer that these things are out there, the more creative...smaller NGOs and...smaller unions will [use] them'. ${ }^{7}$ Even more, the Director of the International Department at the AFL$\mathrm{ClO}$ claims that 'it's a mechanism that should be used by others....We [AFL-ClO] don't have a monopoly on the labor mechanism'. ${ }^{8}$

Regarding the follow up of the public submissions, four of the 31 complaints were withdrawn by the submitters themselves. The US OTLA declined seven and accepted 20 public submissions for review. ${ }^{9}$ Figure 3 illustrates the OTLA's decisions with regard to the actorness of the submissions in relative terms. The assessment reveals that submissions of professional nature, in contrast to the theoretical assumptions, were accepted for review less often than those of non-professional nature. In line with the theoretical arguments, most of the collectively filed submissions were approved by the OTLA whereas only half of the individual submissions did. Fi- nally, most submissions with a transnational base and slightly less than half of the submissions with a national nature were accepted for review, corroborating theoretical suggestions.

In order to substantiate whether the nature of complainants has an effect on the procedural follow-ups, I conduct an in-depth case study with two diverse cases with extreme values (Seawright \& Gerring, 2008, p. 300) regarding the three-dimensional conceptualization of actorness. They are the 2011 submissions against Mexico and against the Dominican Republic, which differ strongly in terms of complainants. While the submission against Mexico was filed by the Mexican Electrical Workers Union (SME) together with 93 signatories, including the AFL-ClO, the ITUC, and many grassroots organizations (collectivism), it was an individual complainant who accused the Dominican Republic of violating labor rights (individualism). Moreover, the former comprises many sector-transcendent and sector-specific trade unions, among other labor advocates (professionalism), whereas the latter came to the Dominican Republic as a catholic priest from Europe, lacking professional labor rights authority (non-professionalism): The clergy's central jurisdictions comprise salvation, meaning, and ultimate concern. Only since the end of the last century has it taken its treatments such as pastoral care, and supervised church attendance and aimed them at other kinds of problems, the first of which were social problems (Abbott, 1988, p. 100). The NAALC submission, furthermore, was the result of a transnational alliance comprising several national and international organizations (transnationalism), in contrast to the CAFTA-DR submission with its national origin (nationalism).

Despite differences in the complainants' actorness, the two cases feature similarities which are important for a comparative assessment. First, both labor complaints were submitted in the same year, which is a necessary

\footnotetext{
${ }^{7}$ Interview, Trade and Globalization Policy Specialist, AFL-CIO, June 14, 2013.

8 Interview, Director of the International Department, AFL-CIO, June 17, 2013.

${ }^{9}$ Reasons for declining submissions included the lack of information substantiating allegations and the consideration that the review would not further the objectives of the corresponding FTA. Available at https://www.dol.gov/ilab/trade/agreements/naalc.htm
} 


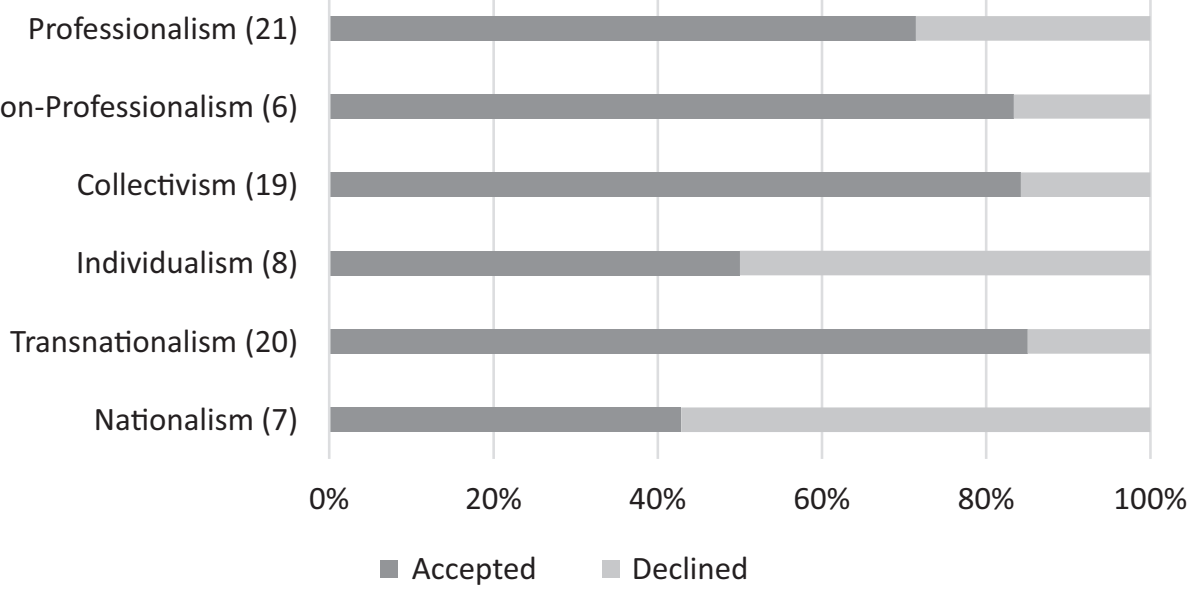

Figure 3. Actorness in public submissions and OTLA decisions.

precondition as different US administrations might react more or less favorable to international labor rights. ${ }^{10}$ Also, being filed more than 15 years after the first complaints and six years ago, they provide the same time period for potential learning effects from preceding submissions and leave enough room for procedural follow-ups, respectively. Second, both address similar labor rights concerns, which is a relevant precondition as certain labor rights violations might be resolved easier than others, thus influencing the complaints' effectiveness. ${ }^{11}$

\subsection{The NAALC and the CAFTA-DR Experience}

The submission against Mexico presented to the OTLA on November 14, 2011 consists of 71 pages, in which the 94 complainants demonstrate how the Government of Mexico has failed to uphold is commitments under the NAALC by not taking action following the issuance of a Presidential decree on October 2009, dissolving the state-owned electrical power company, Central Light and Power, and terminating the employment of over 44,000 SME members. In accordance with its Procedural Guidelines, the OTLA accepted the public submission for review on January 13, 2012. On June 25, 2012 (and noticed in the Federal Register notice on July 2, 2012), the OTLA determined that an extension of time was necessary for its review and issuing of a public report, ${ }^{12}$ normally due within a 180 -day review period. The extension of time was mainly owing to a supplemental submission from the complainants on May 25, 2012, which contained new allegations and required a thorough consideration of the supplemental submission and of information obtained after an OTLA fact-finding visit to Mexico in March 2012. ${ }^{13}$ According to the Acting Associate Deputy Undersecretary, USDOL, the case is 'extremely complicated, with a myriad of claims and documents involved'. ${ }^{14}$ On February 1, 2013, after Supreme Court rulings in Mexico against the SME, the submitters notified the OTLA that they would submit additional information based on recent developments. ${ }^{15}$ The OTLA still lists the case as 'currently under review'. ${ }^{16}$

In contrast to the very comprehensive Mexico submission under the NAALC, the complaint against the Dominican Government presented to the OTLA on December 22, 2011 by a priest features four pages only. The OTLA accepted the submission for review on February 22, 2012. It was noted by the Acting Associate Deputy Undersecretary, USDOL, that the Dominican submission was-in contrast to the Mexican submission-'sparsely detailed' ${ }^{17}$ In order to verify information on the ground, the OTLA took two review trips (April and July) to the Dominican Republic, in which the US delegation met with government, business, and worker representatives. As the OTLA received many comments on the case, it decided to formalize the process by issuing a Federal Register Note soliciting public comments. On August 20, 2012, the OTLA extended the review process due to the amount of information it received. ${ }^{18}$ According to the Acting Deputy Undersecretary, the delays were also due to the complicated nature of the submission. ${ }^{19}$

\footnotetext{
10 Interview Trade and Globalization Policy Specialist, AFL-CIO, June 14, 2013.

11 Both labor rights complaints cite violations of core labor standards as defined by the ILO such as freedom of association and the right to organize.

12 See also https://www.dol.gov/ilab/submissions/pdf/MexicoSubmission2011.pdf

13 See also https://www.federalregister.gov/documents/2012/07/02/2012-16140/north-american-agreement-on-labor-cooperation-notice-of-extensi on-of-the-period-of-review-for

14 Acting Deputy Undersecretary, USDOL, as cited in Minutes of NAC Meeting, September 27, 2012, p. 13, available at https://www.dol.gov/ilab/trade/ agreements/nac.htm

15 Minutes of NAC meeting, March 19, 2013, p. 10, available at https://www.dol.gov/ilab/trade/agreements/nac.htm

16 See also https://www.dol.gov/ilab/trade/agreements/naalc.htm

17 Minutes of NAC meeting, September 27, 2012, p. 16, available at https://www.dol.gov/ilab/trade/agreements/nac.htm

18 Minutes of NAC meeting, September 27, 2012, p. 16, available at https://www.dol.gov/ilab/trade/agreements/nac.htm

19 Minutes of NAC meetings, September 27, 2012, p. 16; March 19, 2013, p. 9, available at https://www.dol.gov/ilab/trade/agreements/nac.htm
} 
The public report of review was finally released on September 27, 2013. It finds evidence of apparent and potential violations of labor law in the Dominican sugar sector. They relate to acceptable conditions of work, child labor, and forced labor. Moreover, the report documents concern with respect to Dominican labor law on freedom of association, the right to organize, and collective bargaining, and with respect to shortcomings in labor inspections. To address these limitations, the report offers eleven recommendations, the implementation of which will be reviewed six and twelve months after publication. In fact, since issuing the public report, the OTLA has published five periodic reviews between April 2014 and October 2016 concerning the recommendations' implementation. While these reports reveal improvements for decent work, the US still deems certain issues not fully addressed by the Dominican Government. ${ }^{20}$

\subsection{David Against Goliath? Influence of Actorness on Decent Work}

Comparing the public submissions against the Mexican Government under the NAALC and against the Dominican Government under the CAFTA-DR, it can be said that the latter is more far-reaching in terms of the procedural steps taken by the US so far, as it has been accepted for review and produced a public report with precise recommendations that have been regularly monitored. This is in contrast to the formulated hypotheses which expect professionalism, collectivism, and transnationalism to be more conducive to successful labor advocacy than non-professionalism, individualism, and nationalism. This section will provide a discussion on how the nature of the complainants contributed to this rather surprising outcome.

In contrast to the NAALC submission, the CAFTA-DR submission was not backed by trade unions or their confederations with professional expertise and experience on labor rights enforcement. In fact, Father Hartley did not seek support by Dominican trade unions as he perceived of unions in the sugar sector as being reluctant to fight for rights of workers with Haitian ethnic background. Instead, he collected relevant information on the working conditions of laborers from the bateyes himself. His engagement and expertise in the field of worker protection was also confirmed by the Director of the OTLA to whom the case was addressed: 'He [Father Christopher Hartley] is a very dedicated person who worked a number of years in the Dominican Republic....I would characterize him as a person with a humanitarian concern about rights of particularly Haitian workers, living conditions. So, I [imagine] his motivation of helping the poor, helping those who are disadvantaged, [seeking justice in] bringing the case forward. I see that passion in his interactions with us'. ${ }^{21}$ In addition to his expertise from the ground, Father Hartley was able to acquire experience with international systems of labor protection by dealing with enforcement procedures in alternative venues beforehand. He expressed concerns to EU authorities in the context of the EU-CARIFORUM Economic Partnership Agreement in 2009 and later in 2013, who took the issues seriously and reached out to Dominican authorities, among other measures (Oehri, 2017, pp. 138-139). Father Hartley also presented a formal complaint to Bonsucro-a non-profit multi-stakeholder organization for sustainable sugar cane production-as a result of which three major sugar cane producers in the Dominican Republic were forced to abandon their membership. Moreover, Father Hartley has been surrounded and supported by experts of international affairs and the US complaint procedure, including former deputy assistant of the USDOL and former ambassador of the EU in the Dominican Republic. ${ }^{22}$

This engagement, even if 'not necessarily...linked to the labor movement', ${ }^{23}$ resulted in a public submission that was able to meet the criteria as requested by the US OTLA to be accepted for review. The missing evidence for the public review was gathered by OTLA officials themselves, including fact finding visits and public information procedures. While the AFL-CIO was not a party to the case, it nevertheless submitted confirming information on the labor rights allegations through the possibility for public comments. ${ }^{24}$

As he could compensate for the lack of trade unions' professionalism, Father Hartley also managed to gain from the non-collective nature of his submission: 'The fact that I was an individual', as Father Hartley claims, 'was not necessarily detrimental. Of course, being an individual, it became a very attractive story to the media. And the media, much more than trade unions or human rights organization, have been my most powerful allies in advancing the course of Haitian migrant workers of the sugar cane fields of the Dominican Republic'. He further believes that the case 'wouldn't be so attractive as a media story if this was Amnesty International or some unknown organization...defending the labor of the Haitian migrant workers. So it has not been entirely to my disadvantage. From the media standpoint, newspapers, documentaries, you name it, it's a very effective story, it's a bit like David against Goliath'. As far as the follow-up procedure of the public submission to the US is concerned, Father Hartley comments that the USDOL was experiencing an enormous pressure from the media to do the right thing.

The limited legitimacy an individual submitter faces could be compensated by Father Hartley as he functioned as a mouthpiece for a work force who lacked a voice itself. However, what Father Hartley could not es-

\footnotetext{
20 See also https://www.dol.gov/agencies/ilab/our-work/trade/fta-submissions

21 Interview, Director, OTLA, USDOL, June 12, 2013.

22 Interview, Christopher Hartley, April 11, 2013; see also https://clarkson-montesinos.org/our-team-2

23 Interview, Director of the International Department, AFL-CIO, June 17, 2013.

24 Interview, Trade and Globalization Policy Specialist, AFL-CIO, June 14, 2013.
} 
cape from were negative personal consequences for his engagement in the fight for workers' rights. His longtime campaign to end illicit labor conditions in the Dominican Republic ended with his expulsion from the country in October 2006. ${ }^{25}$

In contrast to the Mexican submission, the Dominican submission was not presented by a transnational advocacy network. Father Hartley did not seek assistance in the development of a formal complaint by US organizations such as the AFL-CIO. He had the impression that they had not shown any interest in the story. ${ }^{26}$ The AFL-CIO became aware of this initiative only a few days before the submission. ${ }^{27}$ However, the Dominican case suggests that a lack of transnational advocacy does not necessarily mean a lack of transnational awareness and pressure. In fact, given that the priest had presented a similar concern to EU authorities beforehand, officials from the EU and the US have been familiar with each other's cases and observed each other's reactions. ${ }^{28}$ Moreover, international human rights organizations such as Amnesty International and Human Rights Watch became aware of the story and published corresponding reports, thereby reaching out to a global audience. ${ }^{29}$ Besides, the public report resulting from the formal complaint prompted awareness of multinational companies of the illicit labor conditions of sugar producers in the Dominican Republic. The Director of the Global Workplace Rights at The Coca-Cola Company, for instance, reiterated that the public report was useful for their work in remediating the Dominican sugar industry. ${ }^{30}$ Also, the same day in September 2013 the USDOL presented its public report, it announced a USD $10 \mathrm{mil}-$ lion project in the Dominican agriculture sector as part of its commitment to engage with the Government of the Dominican Republic to address the concerns raised in the public submission (Oehri, 2017, p. 75). It remains unclear whether this cooperation project would have been initiated without a public submission and following investigations in the Dominican Republic under the aegis of the CAFTA-DR.

\section{Conclusions}

In a recent assessment of labor standards in trade and investment agreements, the ILO (2016) concluded that 'the impact of labour provisions depends crucially on...the extent to which they involve stakeholders, notably social partners', among other factors. This study is designed to better understand the nature of civil society actors as a potential influencing variable to decent work. Drawing on a multidisciplinary framework of actorness, it reveals that the majority of submissions presented at the
US in the context of FTAs are signed by professional, collective, and transnational parties. Interestingly, nonprofessional submissions were accepted as legal cases more often than professional ones in relative terms whereas collective and transnational submissions were comparatively more successful than individual and national ones. These findings are partly substantiated by the insights of two most different cases, in which the submission of an individual priest was more far-reaching in terms of procedural steps than the submission signed by a collective of over 90 national and international trade unions and other organizations. Thereby, and in addition to further developing extant literature on non-state actors' access (Keohane et al., 2000; Tallberg et al., 2014) by investigating their practical participation, this study's emphasis on the risks and potentials the nature of actorness entails for successful labor rights advocacy gives confidence and guidance to civil society actors who witness illicit labor practices in signatory countries to US FTAs.

\section{Acknowledgments}

I wish to thank Jan Orbie, Gerda Van Roozendaal, Martin Petzke, and the anonymous reviewers for their helpful comments. I am particularly grateful for the generous financial support provided by the Swiss National Centre of Competence in Research (NCCR) Trade Regulation. The views expressed in this article are those of the author and do not necessarily reflect those of the Government of Liechtenstein.

\section{Conflict of Interests}

The author declares no conflict of interests.

\section{References}

Abbott, A. (1988). The system of professions: An essay on the division of expert labor. Chicago, IL and London: The University of Chicago Press.

Compa, L. (2002). A glass half full: The NAFTA Labor Agreement and cross-border labor action. In G. J. Andreopoulos (Ed.), Concepts and strategies in international human rights (pp. 139-161). New York, NY: Peter Lance Publishing.

Compa, L. (2008). Trade unions and human rights. In C. Soohoo, C. Albisa, \& M. F. Davis (Eds.), Bringing human rights home: $A$ history of human rights in the United States (pp. 209-253). Westport, CT: Praeger Publishing.

Dray, P. (2010). There is power in a union: The epic story of labor in America. New York, NY: Doubleday.

\footnotetext{
25 See also https://clarkson-montesinos.org/press-info

26 Interview, Christopher Hartley, April 11, 2013.

27 Interview, Trade and Globalization Policy Specialist, AFL-CIO, June 14, 2013

28 Interview, Director, OTLA, USDOL, June 12, 2013; Interview, Civil Servant, OTLA, USDOL, June 12, 2013; Civil Servant, DG Trade, European Commission, April 29, 2014.

29 Interview, Christopher Hartley, April 11, 2013.

30 Minutes of NAC meeting, February 5, 2013, available at https://www.dol.gov/ilab/trade/agreements/nac.htm
} 
Florini, A. M. (2000). Lessons learned. In A. M. Florini (Ed.), The third force: The rise of transnational civil society (pp. 211-240). Washington, DC: Carnegie Endowment for International Peace.

Freeman, R. B. (1976). Individual mobility and union voice in the labor market. The American Economic Review, 66(2), 361-368.

Freeman, R. B., \& Hersch, J. (2005). Introduction. In R. B. Freeman \& J. Hersch (Eds.), Emerging labor market institutions for the twenty-first century (pp. 1-12). Chicago, IL and London: University of Chicago Press.

Hall, P. A., Jacoby, W., Levy, J., \& Meunier, S. (2014). Introduction. The politics of representation in the global age. In P. A. Hall, W. Jacoby, J. Levy, \& S. Meunier (Eds.), The politics of representation in the global age: Identification, mobilization, and adjudication (pp. 1-28). Cambridge: Cambridge University Press.

International Labor Organization. (2016). Assessment of labour provisions in trade and investment arrangements. International Labor Organization. Retrieved from http://www.ilo.ch/global/publications/ books/WCMS_498944/lang--en/index.htm

Johnson, R. (2000). Advocates and activists: Conflicting approaches on nonproliferation and the test ban treaty. In A. M. Florini (Ed.), The third force: The rise of transnational civil society (pp. 49-81). Washington, DC: Carnegie Endowment for International Peace.

Keck, M. E., \& Sikkink, K. (1999). Activists beyond borders: Advocacy networks in international politics. Ithaca, NY and London: Cornell University Press.

Keohane, R. O., Moravcsik, A., \& Slaughter, A.-M. (2000). Legalized dispute resolution: Interstate and transnational. International Organization, 54(3), 457-488.

Kidder, T. G. (2002). Networks in transnational labor organizing. In S. Khagram, J. V. Riker, \& K. Sikkink (Eds.), Restructuring world politics: Transnational social movements, networks and norms (pp. 269-293). Minneapolis, MN and London: University of Minnesota Press.
Nolan García, K. A. (2011a). The evolution of United States-Mexico labor cooperation (1994-2009): Achievements and challenges. Politics \& Policy, 39(1), 91-117.

Nolan García, K. A. (2011b). Transnational advocates and labor rights enforcement in the North American Free Trade Agreement. Latin American Politics and Society, 53(2), 29-60.

Oehri, M. (2017). US and EU external labor governance: Workers' rights promotion in trade agreements and in practice. Basingstoke: Palgrave Macmillan.

Risse, T. (2000). The power of norms versus the norms of power: Transnational civil society and human rights. In A. M. Florini (Ed.), The third force: The rise of transnational civil society (pp. 177-209). Washington, DC: Carnegie Endowment for International Peace.

Seawright, J., \& Gerring, J. (2008). Case selection techniques in case study research: A menu of qualitative and quantitative options. Political Research Quarterly, 61(2), 294-308.

Tallberg, J., Sommerer, T., Squatrito, T., \& Jönsson, C. (2014). Explaining the transnational design of international organizations. International Organization, 68(4), 741-774.

Tilly, C. (1995). Globalization threatens labor's rights. International Labor and Working-Class History, 47, 1-23.

Trubek, D. M., Mosher, J., \& Rothstein, J. S. (2000). Transnationalism in the regulation of labor relations: International regimes and transnational advocacy networks. Law and Social Inquiry, 25(4), 1187-1211.

Van Roozendaal, G. (2015). The diffusion of labour standards: The case of the US and Guatemala. Politics and Governance, 3(2), 18-33.

Weiss, M. S. (2003). Two steps forward, one step back, or vice versa: Labor rights under Free Trade Agreements from NAFTA through Jordan via Chile to Latin America and beyond. University of San Francisco Law Review, $37,689-755$.

\section{About the Author}

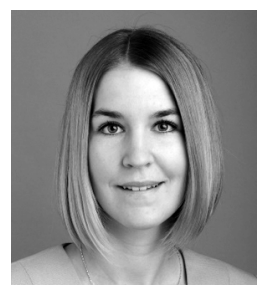

Myriam Oehri (PhD) was a lecturer at the Global Studies Institute and the Department of Political Science and International Relations, University of Geneva, and the Department of Political Science, University of Lucerne, before serving as a diplomat at the Permanent Mission of Liechtenstein to the UN in New York. She was a visiting scholar at the Centre for EU Studies, Ghent University, and at Harvard Law School, Harvard University, and worked as external collaborator for the ILO. 